\title{
ARTICLE
}

\section{Abundance and size structure of flatfish species on the west side of the Gulf of California, Mexico}

\author{
Abundancia y estructura de tallas de los lenguados en la parte Oeste del Golfo de California, México
}

\author{
Carlos Hiram Rábago-Quiroz ${ }^{1}$, Juana López-Martínez², \\ Manuel O. Nevárez-Martínez ${ }^{3}$ and Enrique Morales-Bojórquez ${ }^{4}$
}

\author{
${ }^{1}$ Instituto Nacional de Pesca, Centro Regional de Investigación Pesquera, La Paz, B.C.S., Carretera a Pichilingue Km. 1 S/N, \\ Col. El Esterito, La Paz, Baja California Sur, 23022, México \\ ${ }^{2}$ Centro de Investigaciones Biológicas del Noroeste SC, Unidad Sonora, Campus Guaymas, Guaymas, Sonora, 85465, México. \\ jlopez04@cibnor.mx \\ ${ }^{3}$ Instituto Nacional de Pesca, Centro Regional de Investigación Pesquera, Guaymas, Sonora, Guaymas, Sonora, 85465, México \\ ${ }^{4}$ Centro de Investigaciones Biológicas del Noroeste SC, La Paz, B.C.S., La Paz, Baja California Sur, 23090, México
}

\begin{abstract}
Resumen.- Algunas especies de lenguados son capturadas incidentalmente con redes de arrastre y algunas de éstas son especies objetivo de una pesquería artesanal en el Golfo de California, México. Con el propósito de conocer cuántos individuos de la población están siendo capturados y cuáles son los efectos de estas capturas, el objetivo de este estudio fue estimar la abundancia de los lenguados capturados incidentalmente con redes de arrastre y en una pesquería artesanal o de pequeña escala en el Golfo de California, y determinar la posible competencia entre flotas (con redes de arrastre y la flota artesanal con redes agalleras) por el mismo recurso. Las muestras fueron recolectadas durante 2002 y 2003 de 3 diferentes fuentes: prospecciones de 2 barcos de la flota camaronera comercial, prospecciones en 2 cruceros de investigación y de una flota artesanal la cual opera a lo largo de la costa del estado de Sonora, México. La abundancia de los lenguados capturados en las redes de arrastre fue estimada usando el método de área barrida y a través de análisis de cohortes por talla fue estimada la abundancia para los lenguados capturados por la flota artesanal. Catorce especies de lenguados fueron identificados en las capturas incidentales con redes de arrastre, destacando Paralichthys woolmani, Etropus crossotus, Citharichthys fragilis, Citharichthys gilberti, Achirus mazatlanus y Syacium ovale. Seis de las 14 especies de lenguados capturados incidentalmente fueron también capturados por la flota artesanal, de la cual el $70 \%$ corresponde a P. woolmani. Se demostró que cada flota opera sobre diferentes fracciones de la población, individuos de 25 a $90 \mathrm{~cm}$ en longitud total fueron capturados por la flota artesanal y los valores de mortalidad por pesca y tasa de explotación fueron $<0,01$, mientras que en las capturas incidentales (flota camaronera) los individuos presentaron tallas entre 4 y $20 \mathrm{~cm}$, demostrando presión de pesca en los individuos juveniles cuya captura podría tener efectos negativos, debido a éstos pueden ser reclutas para la pesca artesanal.
\end{abstract}

Palabras clave: Abundancia, estructura de talla, lenguados, Golfo de California, captura incidental

Abstract.- Some flatfish's species are caught incidentally in bottom-trawls and some of them are the target of an artisanal fishery in the Gulf of California, Mexico. To know the number of individuals removed from a population and the effects of their removal, the aim in this study was to estimate the abundance of flatfishes caught as bycatch in bottom-trawls and by artisanal or small-scale fishery in the Gulf of California and determinate the possible competition between fleets (bottom-trawl and artisanal with gillnets) for the same resource. During 2002 and 2003, samples were collected from 3 sources: (1) surveys of 2 vessels from the shrimp trawl fleet; (2) surveys in 2 research cruisers; and (3) from an artisanal fleet operating in the coast of the state of Sonora, Mexico. Abundance of flatfishes caught in bottom-trawls was estimated using the swept area method, and through the catch-at-size analysis for the flatfishes caught by the artisanal fishery. Fourteen flatfish species were identified as bycatch in the bottom-trawl, of which those that stand out in abundance were: Paralichthys woolmani, Etropus crossotus, Citharichthys fragilis, Citharichthys gilberti, Achirus mazatlanus and Syacium ovale. Six of the 14 flatfishes incidentally captured by the shrimp fleet were caught by artisanal fishery, of which $70 \%$ consist of P. woolmani. Each fleet operated on different population fractions; sizes from 25 to $90 \mathrm{~cm}$ in total length were obtained by the artisanal fleet with fishing mortality values and exploitation rates-at-size $<0.01$ while bycatch in the shrimp fleet consisted of individuals from 4 to $20 \mathrm{~cm}$, which shows fishing pressure on younger individuals. However, removals of these young individuals could have negative effects because they could be recruits for artisanal fishery.

Key words: Abundance, size structure, flatfish, Gulf of California, incidental capture 


\section{INTRODUCTION}

One of the main impacts of trawling is bycatch (incidental captures including retained and discarded species), usually resulting from absence of selectiveness of fishing gear (Pope et al. 2000, Davis 2002). According to estimates from the Food and Agriculture Organization of the United Nations (FAO), shrimp trawling in tropical areas generate approximately 1.86 million metric tons of bycatch, $27.3 \%$ of the total bycatch of commercial fisheries of the world (Kelleher 2005).

Bottom trawling, especially the shrimp fishery in the Gulf of California, is one of the most important sources of income and employment for communities along the coast (López-Martínez et al. 2001, Sierra-Rodríguez et al. 2005); however, it represent the greatest bycatch contribution in Mexico. This fishery generates approximately 250,000500,000 ton of discarded fish, crustaceans and mollusks each year (Madrid-Vera et al. 2007, 2010).

Fishes are the most abundant group in the shrimp bycatch from the Gulf of California, which accounts for 95\% of this bycatch (López-Martínez et al. 2010, RábagoQuiroz et al. 2012). The majority of fishes in the shrimp trawl bycatch are small species with little or no economic value (Pérez-Mellado \& Finley 1985, López-Martínez et al. 2010) although some of them have commercial value, including some flatfishes. Flatfish species represent between 5 to $12 \%$ of the total bycatch of the shrimp trawl fishery (Rábago-Quiroz et al. 2008). Larger flatfishes and other species (snappers, finescale triggerfish, and rays) are retained by shrimp trawlers because of their high value in the market, providing extra profit to supplement their incomes.

Due to their high value, flatfishes are target of artisanal or small-scale fishery with small boats and gillnets in some areas near the coast in the Gulf of California. The average production of this resource for the artisanal fishery in Sonora was 175, 192, 180 and 335 metric tons live weight, from 2002 to 2005 (SAGARPA-CONAPESCA 2006).

Incidental capture of some fish species by the bottom trawl fleet has been hypothesized to affect capture yields of artisanal fisheries in the Gulf of California (RodríguezValencia \& Cisneros-Mata 2006). Affected species might include flatfishes, snappers and rays. However, no data are available on the number of individuals removed or the population fraction extracted by each fishery and the effects of these removals.

Bycatch should be examined in the context of biological, ecological, economic, and social impacts to provide a comprehensive evaluation of its overall significance. Its biological impacts have been demonstrated at species, population, and ecosystem levels (Hall et al. 2000, Lewison et al. 2004, Kelleher 2005, Read et al. 2006). Economic impacts may be substantial when current or potential future exploitable biomass is not available for harvest (Pascoe 1997, Larson et al. 1998, Kelleher 2005). When bycatch results in the mortality of endangered or protected species, it is clearly of concern. Other issues arise when mortality of marine resources results in productivity loss of commercially or recreationally important stocks or when bycatch is perceived as waste. For these reasons the aim of our study was to estimate the abundance of flatfishes caught as bycatch in bottom-trawls, as target species in an artisanal fishery and to determinate whether competition occurs between fleets (bottom-trawl and artisanal with gillnets) for the same resource on the west side of Gulf of California.

\section{MATERIALS AND METHODS}

The study area was focused on the coastal waters off the Mexican states of Sonora, Sinaloa (from of Puerto Peñasco southward to the vicinity of Topolobampo, Sinaloa) and Baja California (from San Felipe to San Luis Gonzaga), Mexico. On the western side of the Gulf, the continental shelf is rocky and narrow; the eastern coast is wide, with numerous coastal lagoons to the south (Fig. 1).

\section{Data COLlection}

Samples were collected from three data sources (1) Commercial shrimp fleet (bycatch) collected from the catch of 2 commercial fishing vessels C/V 'María Eugenia' and 'Verónica', each one covering different areas along the coast in the Gulf of California from September to March 2003. (2) Two research cruises in the Gulf of California, Mexico carried out onboard the C/V 'Delly IV' from JulyAugust 2002 and R/V 'BIP XI' from July-August 2003 since these months represent the closed season for shrimp. The stations were spread out across the shrimp trawling grounds and were the same as those sampled annually by Mexican fisheries authorities (INAPESCA) to assess shrimp population status and determine the opening dates for the fishery. (3) Artisanal fishery, specifically the artisanal fleet operating along the coast of the state of Sonora, Mexico.

For the commercial fishery and research survey the demersal fishing gears deployed from the vessels 


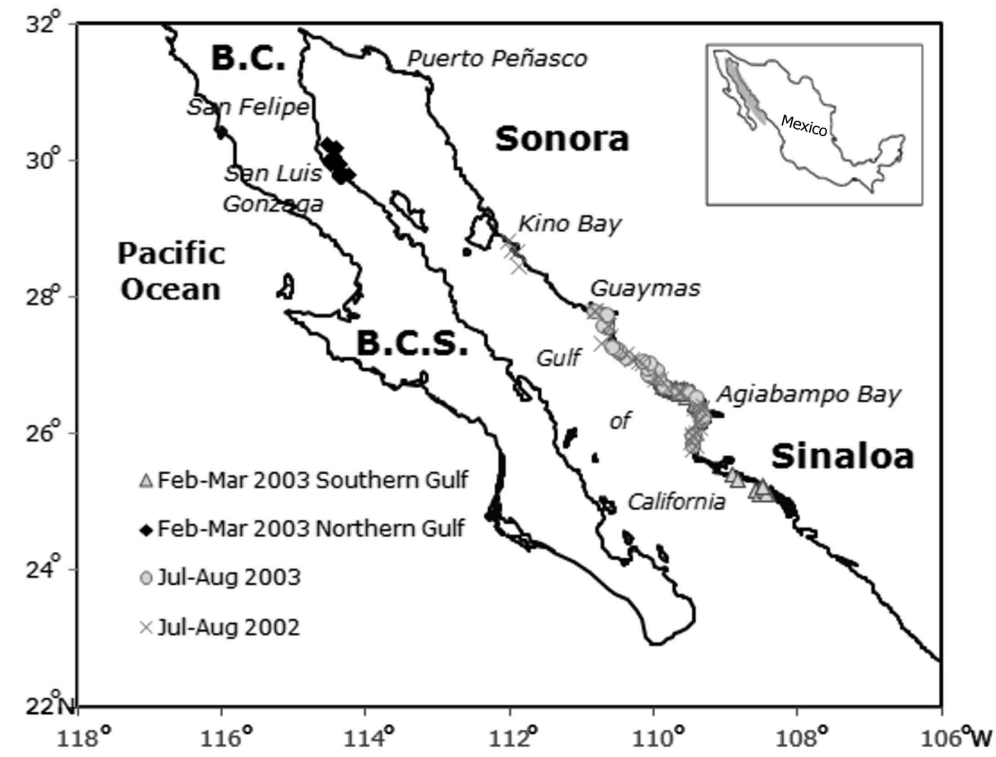

Figure 1. Study area in the Gulf of California, Mexico. Different research survey zones are shown / Área de estudio en el Golfo de California, México. Se muestran las distintas zonas de los cruceros de investigación consisted of paired otter trawls (4.5-5 cm mesh-size), typical of the Gulf of California shrimp fishery. Tows lasted $1 \mathrm{~h}$. Vessel position was tracked using a global positioning system (GPS). At the end of $1 \mathrm{~h}^{-1}$, fishers hauled in the catch and estimated its total wet mass $(\mathrm{kg})$. A sample (20 $\mathrm{kg}$ ) was taken from the catch at each sampling station, following the method proposed by FAO and confirmed according to standard criteria (Box et al. 2008) before it was sorted by fishers as shrimp and valuable fishes. Samples were frozen in plastic bags for on-land processing. In the laboratory, the flatfishes captured were separated from the rest of the fish species, and flatfish were identified using the Mexican Marine Fishes Catalogue (INP 1976), Eschmeyer \& Herald (1983), Hensley (1995), and Robertson \& Allen (2002). Each specimen was measured for total length (TL) and standard length (SL) using a conventional ichthyometer to $1 \mathrm{~mm}$ precision. For artisanal fishery the sampling was conducted in 2003 in 2 different places where the artisanal fleet of Sonora operates (Kino Bay, El Choyudo). We recorded the species identity, TL, SL and weight of each flatfish captured. The fishing gears used for the artisanal fleet of Sonora were gillnets.

Two quantitative analyses were applied in our study. The first one (abundance estimation by the swept area method) was done using research survey data, and the second was an assessment using catch-at-size analysis. For both analyses, the central theme was the need to address and incorporate uncertainty because bycatch occurs when fishing operations result in discard of fish and invertebrates or interactions with marine mammals, seabirds, and sea turtles. Discard of fish may occur because certain species, sexes, or sizes are not marketable or they are of lower value than other catch components or because regulations prohibit the retention of specific species, sexes, or sizes (Lewinson et al. 2004). The main consequence of these data limitations is the introduction of uncertainty, both in available and unknown or missing data.

Studies based on knowledge of life history and population parameters can help provide a pragmatic option for preliminary evaluation of the effects of shrimp trawls on the fish species caught incidentally (Foster \& Vincent 2010) which implies that appropriate life-history information, where available, will provide an insight into trawling impacts through length-based and qualitative approaches. The need for a quantitative analysis is a priority to obtain additional information and establish a baseline or biological reference points for tracking changes in bycatch over time; these measures could be used to assist in guiding policy design and setting priorities (Caddy \& Mahon 1995). 


\section{LENGTH-FREQUENCY DISTRIBUTION ANALYSIS}

The lengths of the flatfish captured by the trawl net were represented as length-frequency histograms of the main species captured. To statistically determine the estimated mean values and standard deviations, a multimodal analysis was done using the following equation:

$$
P\left\{x_{i} \mid n, p_{1}, p_{2}, \ldots ., p_{k}\right\}=n ! \prod_{i=1}^{k} \frac{p_{i}^{x_{i}}}{x_{i} !}
$$

where, $P$ denotes probability, $x_{i}$ is the number of times an event type $i$ occurs in $n$ samples, and $p_{i}$ is the separate probability of each one of the type $k$ events possible. To estimate model parameters it is necessary to transform equation (1) into a likelihood expression; therefore, the new equation is:

$$
-\ln L\left\{x_{i} \mid n, p_{1}, p_{2}, \ldots ., p_{k}\right\}=\sum_{i=1}^{k}\left[x_{i} \ln \left(p_{i}\right)\right]
$$

The main assumption for parameter estimation is that size distribution for each mean length or mode can be analyzed with normal distribution to determine that each mode corresponds to a different cohort in the population. Under this condition, the estimations of the relative expected proportions of each length category $\left(\mathrm{P}_{\mathrm{T}}\right)$ were described using the density function:

$$
P_{T}=\left[\frac{1}{\sigma_{T} \sqrt{2 \pi}} \times e^{\frac{-\left(L_{T}-\mu_{T}\right)^{2}}{2 \sigma_{T}}}\right] \lambda_{T}
$$

where, $\mu_{\mathrm{T}}$ and $\sigma_{\mathrm{T}}$ are the mean and standard deviation of the total length from each cohort and subscript $\mathrm{T}$ means total length. In equation $3 \lambda$ is a value penalizing the $\mathrm{P}_{T}$ function that forces the objective function to predict the number of the observed frequency distribution (Cerdenares-Ladrón de Guevara et al. 2012). The initial parameters in equation 3 were assigned based on 2 criteria: (1) visual inspection of the frequency distribution data; (2) comparison with the structure mode of previous years (Montgomery et al. 2010). To estimate the expected frequencies and model parameters, it is necessary to compare the estimated and expected values with the negative logarithmic likelihood of the multinomial distribution (-ln $\mathrm{L}\left\{\mathrm{L} \mid \mu_{\mathrm{T}}, \sigma_{\mathrm{T}}\right\}$ ) (Haddon 2001, AguirreVillaseñor et al. 2006).

$$
-\ln L\left\{L \mid \mu_{T}, \sigma_{T}\right\}=-\sum_{i=1}^{\delta} L_{i} \ln \left(\frac{\hat{L}_{i}}{\sum \hat{L}_{i}}\right)
$$

where, $\mu_{\mathrm{T}}$ and $\sigma_{\mathrm{T}}$ are the mean and standard deviation of the total length which correspond to the $\delta$ means that are present in the length frequency distribution of each month. Model parameters were assessed when the negative-loglikelihood function (equation 4) was minimized with a nonlinear fit using Newton's algorithm (Neter et al. 1996). A Student's $t$-test was used to estimate confidence intervals for each estimated mode (Lyman-Ott 1993, Madrid-Vera et al. 2007). Length-frequency distributions were analyzed for research survey cruises in the Gulf of California (2002 and 2003) and for Paralichthys woolmani Jordan \& Williams, 1897 caught by artisanal fleets off Sonora, Mexico.

\section{Abundance ESTIMATION by THE SWEPT AREA METHOD}

Abundance estimates for each flatfish species using the swept area method were calculated from research cruises and commercial shrimp fishery data. The swept area is the effective trawling area of one tow in a determinate time and the covered area is the effective covered area during the entire cruise. It was estimated by: $a=W^{*} T V^{*} D$, where $W$ is the effective trawl net width; $T V$ is the towing velocity; and $D$ is the tow duration (standardized to $1 \mathrm{~h}$ ). Once the swept area is estimated, total biomass was given by: $B=C w / v^{*}(A / a)$, where $C w$ is the catch per unit effort; $v$ is vulnerability of prawns to the net; $A$ is the total area; and $a$ is the swept area. Vulnerability of prawns and fish to trawling nets is difficult to estimate (King 1997). Values ranging from 0.5 to 1.0 are normally assumed, so in this case a value of 1.0 was adopted. Dimensions of the covered areas (A) in each sampling were obtained using the geographic position of each haul.

\section{Abundance estimation based on Catch-at-size ANALYSIS}

Abundance was estimated through the catch-at-size analysis (CASA). The biomass-based CASA method proposed here relies on widely available length composition data and is suitable for data deficient situations. This method was proposed by Jones (1984) and is essentially a virtual population analysis on a pseudo-cohort that can also be performed on catch length-frequency distribution. The data required included length-frequency distribution of the catch representing the pseudo-cohort, a natural mortality vector, an estimate of terminal fishing mortality, and length-weight relationship. 
This statistical procedure was applied to $P$. woolmani, which was the most abundant species in the artisanal captures, and its catch in number of individuals grouped as length-frequency distributions allowed making an unbiased abundance estimate using cohort analysis based on sizes. For this analysis complimentary sources of data were necessary, primarily: areas, seasonality, and statistical data on the catches of the 2003 fishing season from the artisanal fleet of Sonora, Mexico. The information was provided by the Fishery Statistics Department of the state of Sonora. Additional, biological samples of this species were obtained monthly from the artisanal fleet from different sites in Sonora (Kino Bay, El Choyudo), during the 2003 fishing season.

Since the information on flatfish catches from artisanal fisheries is declared in volume (weight), an expansion factor was estimated to extrapolate the size structure obtained in the samples to the catches, and hence continue with the estimation of abundance. For this propose, it was necessary to estimate a biometric totallength/total-weight relationship $\left(\mathrm{W}=\alpha \mathrm{L}^{\mathrm{b}}\right)$ obtained by linear regression and using the coefficient of determination $\left(r^{2}\right)$ as best-fit criteria, where $W$ is total weight $(\mathrm{g}) ; L$ is total length $(\mathrm{cm}) ; \alpha$ is the average condition factor; and $\beta$ is the allometric coefficient indicating isometric growth when equal to 3 and allometric growth when significantly different from 3 (Esmaeili \& Ebrahimi 2006, Aguirre-Villaseñor et al. 2008). The estimated value of $\beta$ was analyzed using the Student's $t$ test (Sokal \& Rohlf 1995, Zar 1999) to determine whether growth was isometric or allometric. The estimated lengthweight relationship was used to estimate the average weight for each size interval whose average value was multiplied by the frequency in the respective size interval enabling the total annual weight to be estimated (Sparre $\&$ Vennema 1998). Finally, the catch expressed as number of individuals was estimated from $C_{m i}=h * f_{m i}$, where $C_{m i}$ is the catch (number of organisms) for the size interval $i$, $\eta$ is the expansion factor and $f_{m i}$ is the frequency of the size interval $i$. The $\eta$ value was estimated as

$$
\eta=\sum_{i=1}^{n} W_{c}
$$

where $W_{c}$ is the total catch per month, and $W_{m}$ is the weight of the sample (Gulland \& Rosenberg 1992).

Additionally, to demonstrate significant differences among frequency distributions of Paralichthys woolmani, Pearson's Chi-Square Test $\chi^{2}$ was applied to measure a goodness of fit between the observed and expected values (Zar 1999):

$$
\chi^{2}=\sum_{i=1}^{k} \frac{(o i-e i)^{2}}{e i} ;
$$

where $o_{i}$ is size frequency of shrimp trawl fishery/research cruise specimens and $e_{i}$ is that of artisanal fishing specimens.

\section{Results}

\section{IDENTIFIED SPECIES}

During our study 1,110 flatfish captured by the shrimp trawlers were analyzed. Individuals were caught during 61 shrimp trawl samples; 9 shrimp trawls were carried out during 2002 and 50 during 2003. A total of 14 species were identified: Paralichthys woolmani, Paralichthys californicus (Ayres, 1859); Citharichthys gilberti Jenkins \& Evermann, 1889; Citharichthys fragilis Gilbert, 1890; Achirus mazatlanus (Steindachner, 1869); Etropus crossotus Jordan \& Gilbert, 1882; Etropus peruvianus Hildebrand, 1946; Syacium ovale (Günther, 1864); Symphurus chabanaudi Mahadeva \& Munroe, 1990; Symphurus fasciolaris Gilbert 1892; Pleuronichthys verticalis Jordan \& Gilbert, 1880; Hippoglossina stomata Eigenmann \& Eigenmann, 1890; Citharichthys xanthostigma Gilbert, 1890, and Bothus constellatus (Jordan, 1889).

\section{LENGTH-FREQUENCY DISTRIBUTIONS}

Length-frequency distributions of flatfish species during 2002 and 2003 were different among species (Table 1). The size classes estimated varied between 1 and 4 . Flatfish with only one size class were Paralichthys woolmani, Citharichthys fragilis and Etropus peruvianus. A size class was also estimated for a group of flatfish not identified at species level (other flatfish). Two size classes were estimated for Etropus crossotus, and Citharichthys gilberti. Only Syacium ovale had 3 size classes while 4 size classes were estimated for Achirus mazatlanus and Symphurus chabanaudi (Fig. 2). The estimated values of the mean and confidence intervals ( $t$ distribution, $P<$ 0.05 ) of the length of each size group are shown in Table 1. The population structure of four size classes estimated for Achirus mazatlanus and Symphurus chabanaudi showed total lengths greater than those estimated for Etropus peruvianus $(88.5 \mathrm{~mm})$, and Paralichthys 
woolmani $(76.3 \mathrm{~mm})$. In contrast, for the artisanal flatfish fishery off Sonora, Mexico, the size classes estimated were larger than those observed from research survey data. In artisanal fisheries one size class was estimated for $P$. woolmani; the mean value was $36.4 \mathrm{~cm}$ and the confidence interval was between 35.8 and $37.2 \mathrm{~cm}$ total length (Fig. 3). According to the frequency data of $P$. woolmani the occurrence of size classes larger than 36.4 $\mathrm{cm}$ is possible; however, the data did not show statistically identifiable size classes.

\section{AbUndanCe ESTIMATES BY THE SWEPT AREA METHOD}

Dimensions of the covered and swept areas during the study are shown in Table 2. For abundance estimates by area the following was found: from July-August 2002, the most abundant flatfish species were Etropus crossotus and Citharichthys gilberti; from February-March 2003, Paralichthys woolmani and Achirus mazatlanus were the most abundant; from February-March 2003 in a different area, Citharichthys fragilis, Achirus mazatlanus and Paralichthys woolmani were abundant; and finally from July-August 2003, Achirus mazatlanus and Etropus crossotus were the most abundant flatfish species. In contrast, Hippoglossina stomata, Paralichthys californicus and Citharichthys xanthostigma showed low abundances (Table 2).

Table 1. Number of size classes estimated for flatfish species in the Gulf of California from research survey data. The mean value of the size class is in bold $(\mathrm{mm})$ and the confidence intervals are shown in parenthesis $(\mathbf{m m})$ / Número clases de talla estimadas para las especies de lenguados en el Golfo de California a partir de datos de cruceros de investigación. El valor medio de la clase de talla está en negrita $(\mathrm{mm})$ y los intervalos de confianza se muestran en paréntesis $(\mathrm{mm})$

\begin{tabular}{|c|c|c|c|c|}
\hline Species & Size class 1 & Size class 2 & Size class 3 & Size class 4 \\
\hline Paralichthys woolmani & $\begin{array}{c}\mathbf{7 6 . 3} \\
(74.1-78.7)\end{array}$ & & & \\
\hline Citharichthys fragilis & $\begin{array}{c}\mathbf{1 6 9 . 2} \\
(166.7-171.8)\end{array}$ & & & \\
\hline Achirus mazatlanus & $\begin{array}{c}\text { 101.2 } \\
(99.1-103.1)\end{array}$ & $\begin{array}{c}\mathbf{1 5 5 . 1} \\
(153.3-156.9)\end{array}$ & $\begin{array}{c}\mathbf{2 0 6 . 9} \\
(203.6-210.2)\end{array}$ & $\begin{array}{c}\mathbf{2 9 0} \\
(289.4-290.7)\end{array}$ \\
\hline Etropus crossotus & $\begin{array}{c}\mathbf{1 3 7 . 2} \\
(134.9-139.5)\end{array}$ & $\begin{array}{c}\mathbf{2 0 3 . 7} \\
(196.9-210.7)\end{array}$ & & \\
\hline Citharichthys gilberti & $\begin{array}{c}111.6 \\
(106.1-117.2)\end{array}$ & $\begin{array}{c}\mathbf{2 1 0 . 4} \\
(208.1-214.8)\end{array}$ & & \\
\hline Symphurus chabanaudi & $\begin{array}{c}\mathbf{1 2 4 . 1} \\
(120.9-127.4)\end{array}$ & $\begin{array}{c}\mathbf{1 6 9 . 9} \\
(169.1-170.9)\end{array}$ & $\begin{array}{c}\mathbf{2 2 1 . 5} \\
(216.3-226.8)\end{array}$ & $\begin{array}{c}\mathbf{3 4 3 . 9} \\
(343.5-344.4)\end{array}$ \\
\hline Syacium ovale & $\begin{array}{c}\mathbf{1 0 5 . 9} \\
(102.2-109.7)\end{array}$ & $\begin{array}{c}\mathbf{1 7 1 . 7} \\
(169.8-173.7)\end{array}$ & $\begin{array}{c}\mathbf{2 6 8} \\
(260.6-275.5)\end{array}$ & \\
\hline Etropus peruvinus & $\begin{array}{c}\mathbf{8 8 . 5} \\
(80.2-96.8)\end{array}$ & & & \\
\hline Other flatfish & $\begin{array}{c}92.1 \\
(90.6-93.7)\end{array}$ & & & \\
\hline
\end{tabular}

Table 2. Swept and covered areas from research cruise and shrimp fleet surveys in the Gulf of California during 2002 and 2003 / Área barrida y cubierta a partir de cruceros de investigación y prospecciones de la flota camaronera en el Golfo de California durante 2002 y 2003

\begin{tabular}{lccccc}
\hline Month/Year & Survey & Hauls & $\begin{array}{c}\text { Trawl } \\
\text { distance } \\
(\mathrm{km})\end{array}$ & $\begin{array}{c}\text { Swept } \\
\text { area } \\
\text { (ha) }\end{array}$ & $\begin{array}{c}\text { Covered } \\
\text { area } \\
\text { (ha) }\end{array}$ \\
\hline Jul-Agu 2002 & Research Cruise & 9 & 40.5 & 182 & 359,289 \\
Feb-Mar 2003 & Shrimp Fleet & 18 & 226.5 & 884 & 213,241 \\
Feb-Mar 2003 & Shrimp Fleet & 23 & 278 & 1,084 & 133,890 \\
Jul-Agu 2003 & Research Cruise & 9 & 29.9 & 117 & 369,003 \\
& Total & 59 & 574.9 & 2,267 & \\
\hline
\end{tabular}



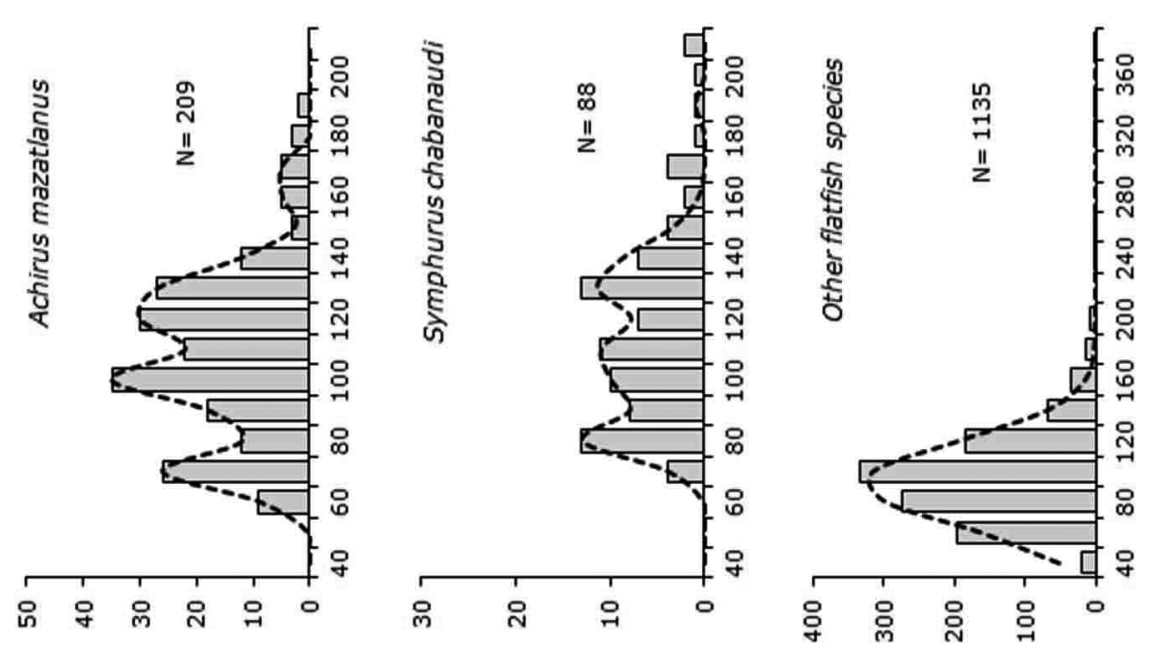

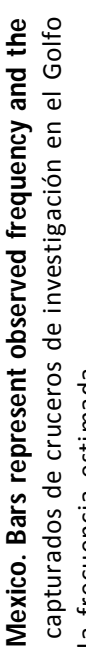
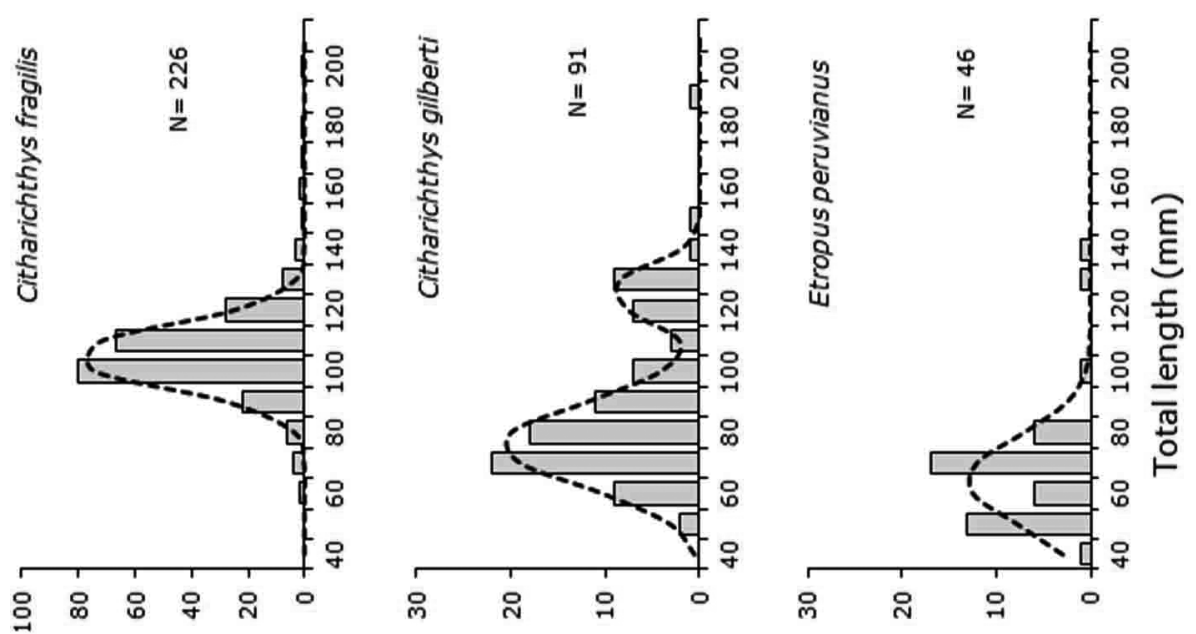

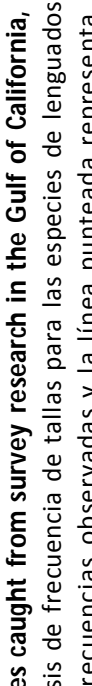
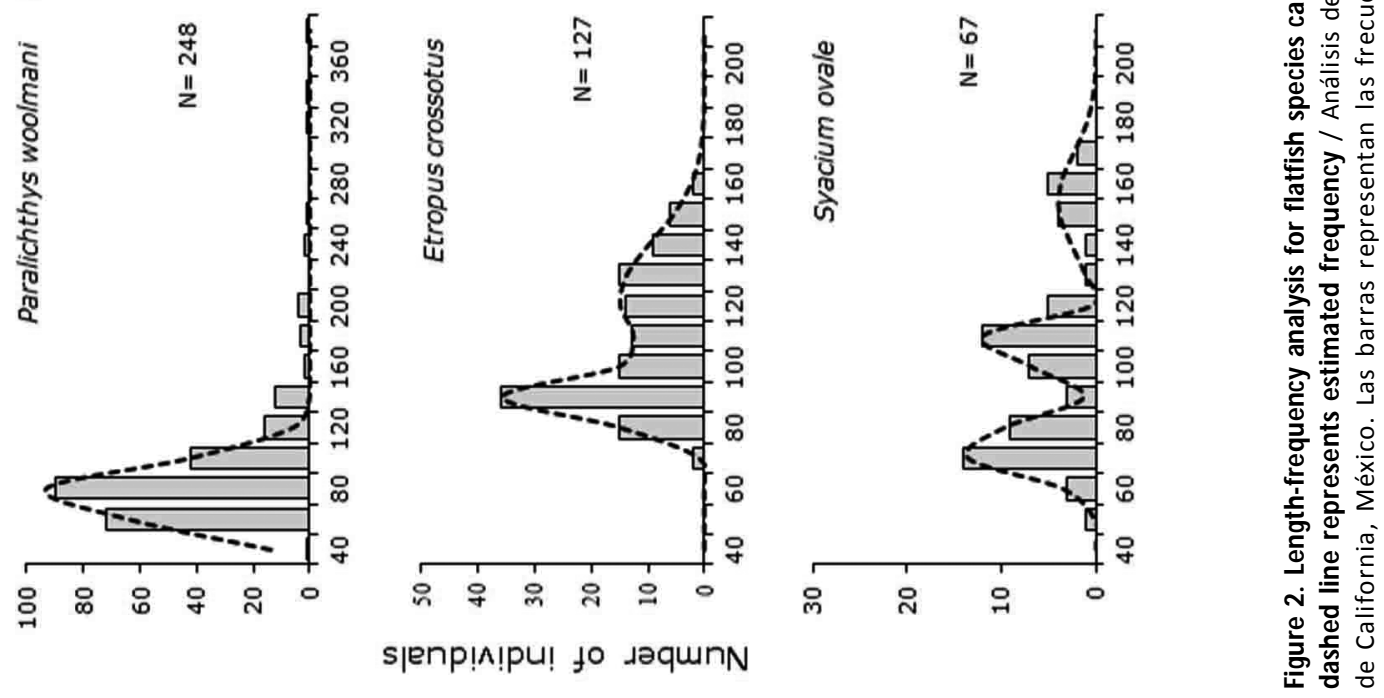

Vol. 50, № 2,2015 241 


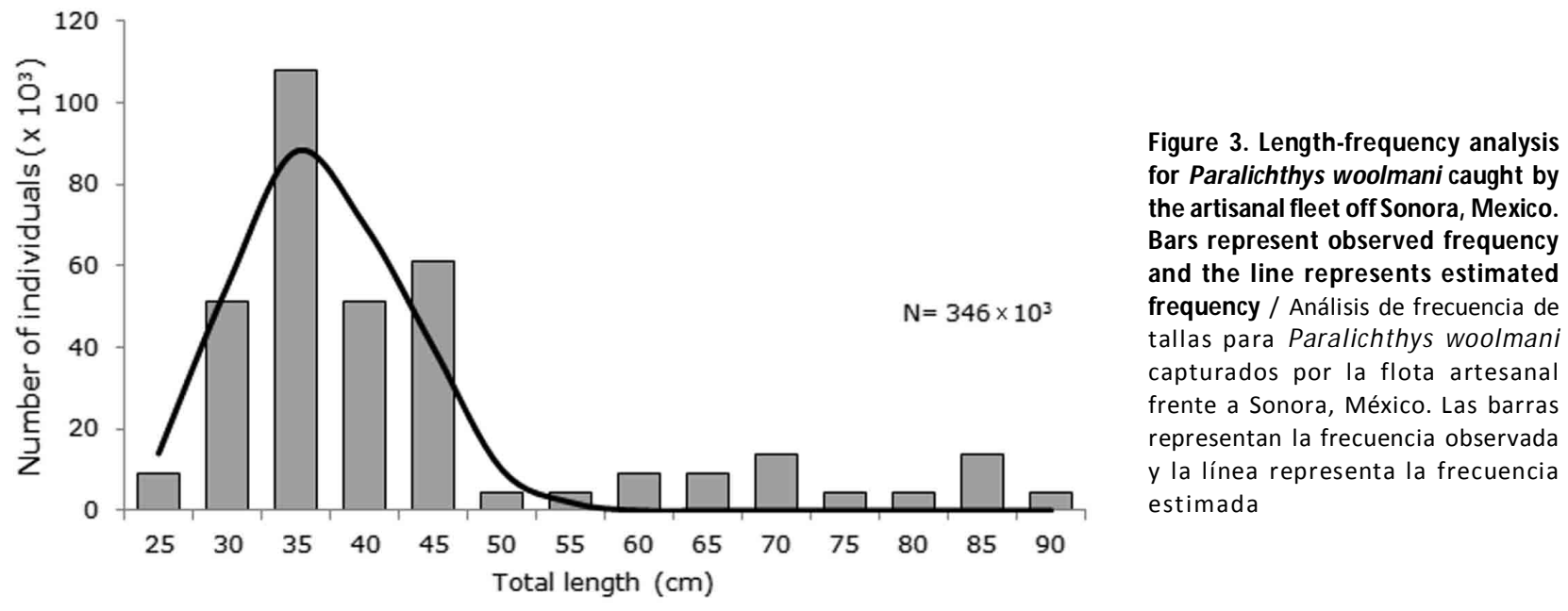

Table 3. Number of individual $\left(\times 10^{6}\right)$ estimates for flatfish species in the Gulf of California from research survey data. The confidence intervals are shown in parenthesis / Número de individuos (x 106) estimado para las especies de lenguados en el Golfo de California a partir de datos de crucero de investigación. Los intervalos de confianza se muestran entre paréntesis

\begin{tabular}{|c|c|c|c|c|}
\hline Species & Jul-Aug 2002 & $\begin{array}{l}\text { Feb-Mar } 2003 \\
\text { * Southern Gulf } \\
\end{array}$ & $\begin{array}{l}\text { Feb-Mar } 2003 \\
\text { *Northern Gulf }\end{array}$ & Jul-Aug 2003 \\
\hline A. mazatlanus & & $\begin{array}{c}2.961 \\
(2.736-3.186)\end{array}$ & $\begin{array}{c}0.985 \\
(0.919-1.052)\end{array}$ & $\begin{array}{c}13.731 \\
(6.729-20.734)\end{array}$ \\
\hline B. constellatus & & $\begin{array}{c}1.420 \\
(1.398-1.442)\end{array}$ & & $\begin{array}{c}0.327 \\
(0.274-0.379)\end{array}$ \\
\hline C. fragilis & & $\begin{array}{c}0.822 \\
(0.770-0.875)\end{array}$ & $\begin{array}{c}1.384 \\
(1.285-1.484)\end{array}$ & $\begin{array}{c}4.595 \\
(3.055-6.135)\end{array}$ \\
\hline C. gilberti & $\begin{array}{c}3.430 \\
(2.789-4.071)\end{array}$ & $\begin{array}{c}2.228 \\
(2.158-2.298)\end{array}$ & $\begin{array}{c}0.070 \\
(0.068-0.071)\end{array}$ & \\
\hline C. xanthostigma & & & $\begin{array}{c}0.005 \\
(0.004-0.056)\end{array}$ & \\
\hline E. crossotus & $\begin{array}{c}5.745 \\
(4.401-6.888)\end{array}$ & $\begin{array}{c}1.619 \\
(1.543-1.696)\end{array}$ & & $\begin{array}{c}10.973 \\
(8.899-13.046)\end{array}$ \\
\hline E. peruvianus & $\begin{array}{c}1.879 \\
(1.756-2.002)\end{array}$ & & & \\
\hline H. stomata & & & $\begin{array}{c}0.037 \\
(0.033-0.042)\end{array}$ & \\
\hline P. californicus & $\begin{array}{c}2.819 \\
(2.634-3.003)\end{array}$ & & & \\
\hline P. woolmani & & $\begin{array}{c}4.555 \\
(4.350-4.759)\end{array}$ & $\begin{array}{c}0.829 \\
(0.783-0.876)\end{array}$ & $\begin{array}{c}3.702 \\
(2.696-4.707)\end{array}$ \\
\hline P. verticalis & & & $\begin{array}{c}0.009 \\
(0.008-0.011)\end{array}$ & \\
\hline S. ovale & & $\begin{array}{c}0.781 \\
(0.725-0.836)\end{array}$ & $\begin{array}{c}0.155 \\
(0.144-0.166)\end{array}$ & $\begin{array}{c}3.477 \\
(2.240-4.713)\end{array}$ \\
\hline S. chabanaudi & & $\begin{array}{c}1.659 \\
(1.502-1.817)\end{array}$ & $\begin{array}{c}0.131 \\
(0.125-0.136)\end{array}$ & $\begin{array}{c}1.229 \\
(1.136-1.327)\end{array}$ \\
\hline S. fasciolaris & & & $\begin{array}{c}0.023 \\
(0.020-0.026)\end{array}$ & \\
\hline Total & 13.874 & 16.048 & 3.680 & 38.036 \\
\hline
\end{tabular}




\section{Abundance estimation by CATCh-AT-SIZE analysis}

Monthly information obtained from the artisanal fleet during 2003 showed that flatfish were caught throughout the year. March-April and November-December were months of high availability and flatfish catch off Sonora (Table 3). In the artisanal captures, 6 abundant species were identified: Paralichthys californicus, Paralichthys woolmani, Pleuronichthys ocellatus, Pleuronichthys verticalis, Hypsopsetta guttulata, and Achirus mazatlanus. The largest (total length) commercial value species were Paralichthys woolmani and Paralichthys californicus, which comprised $95 \%$ of the catches. The other flatfish species were small (less than $25 \mathrm{~cm}$ TL) and not of commercial value. These species are considered bycatch in the flatfish fishery. The catch of $P$. woolmani was approximately $70 \%$ of the total catch of the artisanal fleet. The size frequency distribution of this species varied from 22 to $92 \mathrm{~cm}$; however the most abundant frequency interval was identified from 25 to $50 \mathrm{~cm}$ (Fig. 2). The total length-total weight relationship estimated for $P$. woolmani was $\mathrm{W}=0.0086 \mathrm{TL}^{3.04}$. The coefficient of determination was $r=0.98$, and the $\beta$ coefficient suggested isometric growth $(\beta=3.04, P<0.05)$. The cohort analysis based on sizes applied to $P$. woolmani showed that the size intervals from 25 to $70 \mathrm{~cm}$ total length were abundant, and the values of fishing mortality-at-size and exploitation rateat-size were $<0.01$ (Table 4 and 5).
The goodness of fit $\chi^{2}$ test showed significant differences between size frequency of $P$. woolmani $\left(\chi_{\text {cal }}^{2}=\right.$ $65.73-\chi_{\text {tab }}^{2}=61.65, P<0.05$, d.f.= 45), which means that each fleet operated on different population fractions (sizes) albeit with slight overlap between them. The shrimp fleet/research cruisers extracted mostly small-sized individuals (4-12 cm TL) while the artisanal fleet extracted larger sizes (30-55 cm TL) (Figs. 1 and 2) likely due to fishing gear selectivity.

Table 4. Monthly flatfish catches ( $t$ ) by the artisanal fleet off Sonora, Mexico during the $\mathbf{2 0 0 3}$ fishing season / Capturas mensuales de lenguados ( $t$ ) de la flota artesanal frente a Sonora, México, durante la estación de pesca del 2003

\begin{tabular}{lrr}
\hline & $\begin{array}{c}\text { Flatfishes } \\
(\mathrm{t})\end{array}$ & $\begin{array}{c}\text { Paralichthys } \\
\text { woolmani } \\
(\mathrm{t})\end{array}$ \\
\hline January & 23.5 & 16.4 \\
February & 16.5 & 11.5 \\
March & 43.5 & 30.4 \\
April & 41.0 & 28.7 \\
May & 26.5 & 18.6 \\
June & 12.0 & 8.4 \\
July & 16.0 & 11.2 \\
August & 1.4 & 1.0 \\
September & 5.7 & 4.0 \\
October & 18.6 & 13.0 \\
November & 40.8 & 28.6 \\
December & 43.3 & 30.3 \\
\hline
\end{tabular}

Table 5. Catch-at-size analysis for Paralichthys woolmani during the $\mathbf{2 0 0 3}$ fishing season / Análisis de captura estructurado por talla para Paralichthys woolmani durante la estación de peces del 2003

\begin{tabular}{ccccc}
\hline $\begin{array}{c}\text { Total } \\
\text { length } \\
(\mathrm{cm})\end{array}$ & $\begin{array}{c}\text { Individuals } \\
\text { caught } \\
\left(\times 10^{3}\right)\end{array}$ & $\begin{array}{c}\text { Abundance } \\
\text { Individuals } \\
\left(\times 10^{6}\right)\end{array}$ & $\begin{array}{c}\text { Annual fishing } \\
\text { mortality } \\
\left(\times 10^{-5}\right)\end{array}$ & $\begin{array}{c}\text { Annual } \\
\text { Exploitation rate } \\
\left(\times 10^{-5}\right)\end{array}$ \\
\hline 25 & 9.3 & 305.3 & 3.1 & 5.4 \\
30 & 51.5 & 285.5 & 18.1 & 31.7 \\
35 & 107.8 & 265.4 & 40.6 & 71.2 \\
40 & 51.5 & 244.9 & 21.1 & 36.9 \\
45 & 60.9 & 224.1 & 27.2 & 47.7 \\
50 & 4.6 & 202.6 & 2.3 & 4.1 \\
55 & 4.6 & 180.7 & 2.6 & 4.6 \\
60 & 9.3 & 158.1 & 5.9 & 10.4 \\
65 & 9.3 & 134.6 & 7.0 & 12.2 \\
70 & 14.0 & 110.1 & 12.8 & 22.4 \\
75 & 4.6 & 84.1 & 5.6 & 9.8 \\
80 & 4.6 & 55.8 & 8.4 & 14.7 \\
85 & 14.0 & 22.7 & 61.8 & 108.4 \\
90 & 4.6 & - & - & - \\
\hline
\end{tabular}




\section{Discussion}

Fishes are the most abundant group in the shrimp bycatch from the Gulf of California, constituting 95\% of the catches (López-Martínez et al. 2010, Rábago-Quiroz et al. 2011). Flatfishes represent about $9 \%$ (5 to $12 \%$ ) of the total bycatch (Rábago-Quiroz et al. 2008). Some of these flatfish species are commercially valuable and are retained by the fishers because of due their high value in the market (Paralichthys woolmani, P. californicus).

Most of the fishes incidentally captured by the shrimp trawlers are small in size (5-25 cm TL). For flatfish species the length-frequency distributions analyzed in our study showed that the gear used in the shrimp trawl fishery had an impact on individuals with a total length of less than $13.7 \mathrm{~cm}$. These individuals are recruits, and as a consequence bycatch of these individuals could represent growth overfishing, which occurs when animals are harvested at an average size that is smaller than the size that would produce the maximum yield (Hilborn \& Walters 1992, Quinn II \& Deriso 1999). In addition, the species of flatfish captured by the shrimp trawlers showed few size groups with the exception of Achirus mazatlanus, Syacium ovale and Symphurus chabanaudi (Fig. 2). The number of size groups could be an indicator of the population condition. Froese (2004) suggested 3 lengthbased indicators to assess a population for overfishing: percentage of retained fish that are a) mature, b) at optimum length and c) mega-spawners. The effect of bycatch on the number of size classes of flatfish provided new insight into the life-history and population parameters of these species. Rábago-Quiroz et al. (2008) found that flatfish species in shrimp trawl bycatch in the Gulf of California were smaller than the first sexual maturation size (more than $60 \%$ of the organisms of each species). Consequently, 2 demographic features such as the number of size groups and a reduction in size at first sexual maturation suggest a negative effect of shrimp trawling on flatfish populations. If small sizes or species show the potential for overfishing, then a re-evaluation of small species status, which have generally been considered resilient to fishing pressures.

In the first analysis (swept area method), the most abundant period was observed during July-August 2003 (survey research); and the lowest abundance was estimated during February-March, 2003 (commercial shrimp trawl). Events that could explain the variability in abundance estimations are the migration habits of some flatfish species, mainly of the genera Paralichthys, Etropus and Achirus, which have a reproductive migration from deep waters to coastal areas (Balart 1996, Reichert 2002). According to Petrakis et al. (2002) and RábagoQuiroz et al. (2008, 2011) both behavior and geographical distribution can be important factors in determining the abundance and catch composition of some species. Migratory marine fauna visit coastal areas within the range of small-scale fisheries, potentially producing high bycatch mortality with serious conservation consequences for vulnerable populations (Stearns 1992). The abundance of fish based on survey research on the bycatch of the shrimp-trawl fishery has been previously reported by Madrid-Vera et al. (2007); estimates over time can be used as indicators of the condition of the populations, and be useful as a baseline for understanding the variability of these species. If bycatch is analyzed from experimental trawls, then indicators such as productivity, population structure and diversity can be estimated (Madrid-Vera et al. 2010).

However, if the species caught as bycatch are also targeted by a fishery, bycatch management is very difficult. This situation occurs in the flatfish fishery in the Gulf of California. The artisanal fleet in Sonora, Mexico catches $P$. woolmani, and although commercial catches consist of individuals larger than $22 \mathrm{~cm}$ total length, the bycatch comprises individuals between $2-17 \mathrm{~cm}$, showing fishing pressure on younger individuals of the population. In contrast, the commercial fishery (artisanal) avoids recruitment overfishing because it has harvest control regulations such as fishing areas and minimum legal size. The existence of uncertainty in biomass can impede progress in conservation efforts because management actions needed to protect a species can be delayed until conclusive evidence is available. Therefore, finding ways to address data uncertainty explicitly is one of the primary challenges for bycatch research in the Gulf of California.

By necessity, bycatch research makes demographic and analytical assumptions; for example, positive logbook data records accurately characterize bycatch or that bycatch rates from one fleet can be used to accurately describe bycatch from another fleet. The challenge is to present the caveats and limitations of these analyses explicitly and show how robust results are in response to deviations from assumptions. An approach was used to assess the dusky dolphin Lagenorhynchus obscurus bycatch in trawl fisheries off Patagonia, Argentina suggesting that trawl bycatch probably exceeds a population threshold of $\mathrm{R} / 2$, where $\mathrm{R}$ represents the upper limit of mortality that a population can sustain before declining (Dans et al. 2003). To consider population-level 
effects of shark bycatch in the Northwest Atlantic pelagic longline fishery, Baum et al. (2003) used bycatch records from logbook data, which cover many more years than the observer data for this fishery. To address probable bias and uncertainty in the fisheries-dependent logbook data, the authors developed a method that only included records of positive (non-zero) bycatch, assuming that, if a positive bycatch value was recorded, it was a correct approximation of the bycatch observed. From this analysis, these authors showed evidence of rapid and substantial declines in large coastal and oceanic shark populations as a result of bycatch in this region.

The commercial flatfish fishery (artisanal) in the Gulf of California is fishing larger individuals than the shrimp fishery (bycatch). Fisheries management is applied to the shrimp trawl fishery, primarily passive management based on a closed fishing season (DOF 2013) ${ }^{1}$; hence the flatfish species in the bycatch is aided by the same management action. According to Casey \& Myers (1998) commandand-control approaches such as fishery closures are often impractical and inadvisable. However, Hall (1996) and Hall \& Mainprize (2005) explained that the spatial and temporal distribution of the target species is relevant. If the distribution of target species and bycatch is similar, then the cost of the closures in terms of target species losses will be high. The key variable is the bycatch to target species ratio in all spatial or temporal strata considered.

When this ratio is high, the potential value of closures is also high. López-Martínez et al. (2011) argue that the shrimp closed season (March to August) in the Gulf of California, equally serves other species of fish bycatch since their reproductive period occurs during this time. They also note that the wide latitudinal and bathymetric distribution of bycatch species (larger than the shrimp fishing areas) has implications for the survival of these species (Rábago-Quiroz et al. 2012). Therefore, the few areas that are inaccessible to shrimp trawls will serve as natural refuge areas for bycatch species at depths where they are mainly caught by the commercial shrimp fishery. Finally, effective management of flatfish in the region depends on understanding the population dynamics of target (shrimp) and flatfish species and related ecosystem processes. Reliable quantitative information on flatfish (bycatch) is essential for the assessment and management process of the shrimp fishery.

\section{ACKNOWLEDGMENTS}

Financial support was received from the CIBNOR grant EP.12, and SAGARPA-CONACYT grant 2003-02-089. The first author thanks the Fishery Laboratory in CIBNOR Guaymas, Sonora, particularly Eloisa Herrera-Valdivia and Rufino Morales-Azpeitia.

\section{LITERATURE CITED}

Aguirre-Villaseñor H, E Morales-Bojórquez, ER MoránAngulo, J Madrid-Vera \& MC Valdez-Pineda. 2006. Biological indicators for the Pacific sierra (Scomberomorus sierra) fishery in the southern Gulf of California, Mexico. Ciencias Marinas 32: 471-484.

Aguirre-Villaseñor H, F Amezcua, J Madrid-Vera \& C Soto. 2008. Length-weight relationship for 21 species from coastal lagoon in the southwestern Gulf of California. Journal of Applied Ichthyology 24: 91-92.

Balart EF. 1996. Pesquería de lenguados. In: Casas-Valdez M \& G Ponce-Díaz (eds). Estudio del potencial pesquero y acuícola de Baja California Sur, pp. 273-285. SEMARNAP, Gob. Edo. BCS, FAO, INP, UABCS, CIBNOR, CICIMAR, CETMAR, La Paz.

Baum JK, RA Myers, DG Kehler, B Worm, SJ Harley \& PA Doherty. 2003. Collapse and conservation of shark populations in the Northwest Atlantic. Science 299: 389392.

Bojórquez LF. 1998. Bycatch utilization in Mexico. Report and Proceedings on the FAO/DFID Expert Consultation on Bycatch Utilization in Tropical Fisheries. Rome, pp. 21-28.

Box EG, JH Stuart \& WG Hunter. 2008. Estadística para investigadores: diseño, innovación y descubrimiento, 639 pp. Wiley, Barcelona.

Caddy JF \& R Mahon. 1995. Reference points for fisheries management. FAO Fisheries Technical Paper 349: 1-83.

Casey JM \& MA Myers. 1998. Near extinction of a large, widely distributed fish. Science 281: 690-692.

Cerdenares-Ladrón de Guevara G, E Morales-Bojórquez, S Ramos-Carrillo \& G González-Medina. 2012. Variation in relative abundance and mean size of the sailfish Istiophorus platypterus caught by the artisanal fleet in the Gulf of Tehuantepec, Mexico. Ciencias Marinas 38: 551562.

Dans S, M Alonso, SN Pedraza \& EA Crespo. 2003. Incidental catch of dolphins in trawling fisheries off Patagonia, Argentina: can populations persist? Ecological Applications 13: 754-762.

${ }^{1}$ DOF (Diario Oficial de la Federación). 2013. Acuerdo por el que se da a conocer el establecimiento de épocas y zonas de veda para la captura de todas las especies de camarón en aguas marinas y de los sistemas lagunarios estuarinos de jurisdicción federal del Golfo de México y Mar Caribe. 30 de abril de 2013. México, D.F. 
Davis MW. 2002. Key principles for understanding fish bycatch discard mortality. Canadian Journal of Fisheries and Aquatic Sciences 59: 1834-1843.

Eschmeyer WN \& ES Herald. 1983. A field guide to Pacific coast fishes of North America. The Peterson field guide series, 336 pp. Houghton Mifflin Company, Boston.

Esmaeili HR \& M Ebrahimi. 2006. Length-weight relationships of some freshwater shes of Iran. Journal of Applied Ichthyology 22: 328-329.

Foster SJ \& CJ Vincent. 2010. Using life-history information to assess potential effects of shrimp trawling on small fishes. Journal of Fish Biology 76: 2434-2454.

Froese R. 2004. Keep it simple: three indicators to deal with overfishing. Fish and Fisheries 5: 86-91.

Gulland JA \& AA Rosenberg. 1992. A review of length-based approaches to assessing fish stocks. FAO Fisheries Technical Paper 323: 1-100.

Haddon M. 2001. Modelling and quantitative methods in fisheries, 465 pp. Chapman \& Hall/CRC, New York.

Hall MA. 1996. On bycatches. Reviews in Fish Biology and Fisheries 6: 319-352.

Hall MA \& BM Mainprize. 2005. Managing by-catch and discards: How much progress are we making and how can we do better? Fish and Fisheries 6: 134-155.

Hensley DA. 1995. Paralichthyidae: Lenguados. In: Fischer W, F Krupp, W Schneider, C Sommer, KE Carpenter \& V Niems (eds). Guía FAO para identificación de especies para fines de la pesca. Pacífico Centro Oriental 3: 1349-1380. FAO, Rome.

Hilborn R \& C Walters. 1992. Quantitative fisheries stock assessment: choice, dynamics and uncertainty, $570 \mathrm{pp}$. Chapman-Hall, New York.

INP. 1976. Catálogo de peces marinos Mexicanos, 462 pp. Instituto Nacional de Pesca, México.

Jennings S, HD Reynolds \& SC Mills. 1998. Life history correlates of responses to fisheries exploitation. Proceedings of the Royal Society B: Biological Sciences 265: 333-339.

Jones R. 1984. Assessing the effects of changes in exploitation pattern using length composition data (with notes on VPA and cohort analysis). FAO Fisheries Technical Paper 256: 1-118.

Kelleher K. 2005. Discarding in the world's fisheries: an update. FAO Fisheries Technical Paper 470: 1-131.

King MG. 1997. Fisheries biology, assessment and management, 341 pp. Fishing News Books, Oxford.

Lewinson RL, LB Crowder, AJ Read \& SA Freeman. 2004. Understanding impacts of fisheries bycatch on marine megafauna. Trends in Ecology \& Evolution 19: 598-604.
López-Martínez J. 2000. Dinámica de la pesquería de camarón café (Penaeus californiensis) en el litoral sonorense y su relación con algunos parámetros océano-atmosféricos. Doctoral Thesis, IPN-Centro Interdisciplinario de Ciencias Marinas, La Paz, B.C.S., México, 161 pp.

López-Martínez J, S Hernández-Vázquez, C RábagoQuiroz, E Herrera-Valdivia \& R Morales-Azpeitia. 2008. Efectos ecológicos de la pesca de arrastre de camarón en el Golfo de California. Estado del arte del desarrollo tecnológico de las artes de pesca. En: La Situación del Sector Pesquero en México, Centro de Estudios para el Desarrollo Rural Sustentable y la Soberanía Alimentaria-CEDRSSA, México, pp. 14-45.

López-Martínez J, E Herrera-Valdivia, J RodríguezRomero \& S Hernández-Vázquez. 2010. Peces de la fauna de acompañamiento en la pesca industrial de camarón en el Golfo de California, México. Revista de Biología Tropical 58: 925-942.

López-Martínez J, J Rodríguez-Romero, NY HernándezSaavedra \& E Herrera-Valdivia. 2011. Population parameters of the Pacific flagfin mojarra Eucinostomus currani (Perciformes: Gerreidae) captured by shrimp trawling fishery in the Gulf of California. Revista de Biología Tropical 59: 887-897.

Lyman-Ott R. 1993. An introduction to statistical methods and data analysis, 380 pp. Duxbury Press, Belmont.

Madrid-Vera J, F Amezcua \& E Morales-Bojórquez. 2007. An assessment approach to estimate biomass of fish communities from bycatch data in a tropical shrimp-trawl fishery. Fisheries Research 83: 81-89.

Madrid-Vera J, E Visauta-Girbau \& H Aguirre-Villaseñor. 2010. Composition of trawl catch off the mouth of the Rio Baluarte, Southeastern Gulf of California. Marine Ecology Progress Series 403: 145-153.

Montgomery SS, CT Walsh, M Haddon, CL Kesby \& D Johnson. 2010. Using length data in the Schnute model to describe growth in a metapeneid from waters off Australia. Marine and Freshwater Research 61: 1435-1445

Neter J, MH Kutner, W Wasserman \& J Nachtschien. 1996. Applied linear statistical models, 1408 pp, McGraw-Hill/ Irwin, Chicago.

Pérez-Mellado J \& LT Findley. 1985. Evaluación de la ictiofauna acompañante del camarón en las costas de Sonora y norte de Sinaloa, México En: Yañez-Arancibia A (ed). Recursos pesqueros potenciales de México: La pesca acompañante del camarón, pp.149-200. UNAM-INP, México.

Petrakis G, DN MacLenna \& AW Newton. 2002. Day-night and depth effects on catch rates during trawl surveys in the North Sea. ICES Journal of Marine Science 58: 50-60. 
Pope JG, DS MacDonald, JD Reynolds \& S Jennings. 2000. Gauging the impact of fishing mortality on non-target species. ICES Journal of Marine Science 57: 689-696.

Quinn II T \& R Deriso. 1999. Quantitative fish dynamics, 542 pp. Oxford University Press, Oxford.

Rábago-Quiroz CH, J López-Martínez, E Herrera-Valdivia, MO Nevárez-Martínez \& J Rodríguez-Romero. 2008. Population dynamics and spatial distribution of flatfish species in shrimp trawl bycatch in the Gulf of California. Hidrobiológica 18: 177-188.

Rábago-Quiroz CH, J López-Martínez, JE Valdez-Holguín \& MO Nevárez-Martínez. 2011. Distribución latitudinal y batimétrica de las especies más abundantes y frecuentes en la fauna acompañante del camarón del Golfo de California, México. Revista Biología Tropical 59: 255-267.

Rábago-Quiroz CH, J López-Martínez, JE Valdez-Holguín, MO Nevárez-Martínez \& A Acevedo-Cervantes. 2012. Fish assemblages in the bycatch of bottom shrimp trawl on the west side of the Gulf of California, México. Marine Biology Research 8: 865-876.

Reichert MJ. 2002. One the life history of the fringed flounder (Etropus crossotus) a small tropical flatfish in the south Atlantic Bight. PhD dissertation, Rijksuniversiteit Groningen, 214 pp.

Robertson DR \& GR Allen. 2002. Shorefish of the tropical eastern Pacific: An information system. Smithsonian Tropical Research Institute, Balboa, Panamá. [CD-ROM]
Rodríguez-Valencia JA \& MA Cisneros-Mata. 2006. Captura incidental de las flotas pesqueras ribereñas del Pacífico Mexicano. Reporte Técnico del Programa Golfo de California de WWF-México a la Comisión de Cooperación Ambiental de América del Norte, 127 pp.

SAGARPA-CONAPESCA. 2006. Anuario estadístico de pesca 2005, 305 pp. Secretaría de Agricultura, Ganadería, Desarrollo Rural, Pesca y Alimentación, Comisión Nacional de Acuacultura y Pesca, México.

Sierra-Rodríguez P, C Acosta-Castañeda, JA GarcíaBorbón, AR García-Juárez, A Liedo-Galindo \& JM Melchor-Aragón. 2005. Camarón. En: Sustentabilidad y Pesca Responsable en México 1999-2000. Pesquerías del Océano Pacífico, pp. 5-50. Instituto Nacional de la Pesca, Mazatlán.

Sokal R \& J Rohlf. 1995. Biometry: The principles and practice of statistics in biological research, $902 \mathrm{pp}$. Blume Editions, San Francisco.

Sparre P \& SC Vennema. 1998. Introduction to tropical fish stock assessment. Part 1. Manual. FAO Fisheries Technical Paper 306: 1-337.

Stearns SC. 1992. The evolution of life histories, $262 \mathrm{pp}$. Oxford University Press, Oxford.

Zar JH. 1999. Biostatistical analysis, 944 pp. Prentice-Hall, Englewood Cliffs. 